\title{
Contribution of Isotopic Techniques in the Hydrological Study of the Aquifers of Ica, Villacuri and Lanchas
}

\author{
Rubén Rojas Molina \\ Consultant, Peru \\ E-mail: rrmx123@hotmail.com
Gerardo Maghella Seminario (Corresponding author)
Instituto Peruano de Energia Nuclear, Peru
E-mail: gmaghella@ipen.gob.pe
José Maguiña León
Instituto Peruano de Energia Nuclear, Peru
E-mail: jmaguina@ipen.gob.pe \\ Mirella Tejerina Caisan \\ Universidad Nacional Agraria La Molina, Peru \\ E-mail: mtejerina@unalm.edu.pe
}

Received: November 1, 2019 Accepted: April 11, 2020 Published: May 3, 2020

doi:10.5296/emsd.v9i2.16954

URL: https://doi.org/10.5296/emsd.v9i2.16954

\begin{abstract}
Ica Aquifer located at the coastal zone of Ica River Valley, supplies $40 \%$ of the water to a number of farms of Ica Region which is one of the most productive valley of Peru that covers an area of 30,000 hectares of area, in which a diverse agricultural product are grown for local and external market. In the last 15 years, water-table of the aquifer was lowering at an elevated rate that concerned to farmers and authorities of the Peruvian Government, so a number of studies was carried out to increase the water supply to the agriculture areas.

The main purpose of the study using isotope techniques, was to have a first insight of the
\end{abstract}


hydrodynamics of Ica, Villacuri and Lanchas Aquifers and the possible interconnection between them and with Pisco River. For such purpose, 31 wells, lakes, rivers and springs of Ica and Pisco Basin where sampled during the years 2014 to 2016 both in rain and dry seasons, getting 189 samples for isotope and chemical analysis. The sampling schedule didn't include rain sampling, instead of it, selected springs were sampled and nearby basin rain data was used.

${ }^{18} \mathrm{O},{ }^{2} \mathrm{H}$ and ${ }^{13} \mathrm{C}$ stable isotopes and ${ }^{3} \mathrm{H},{ }^{14} \mathrm{C}$ radioactive isotopes of the water samples were analyzed in the laboratory of "Isotope Tracer Technologies INC"; the results of the stable isotope analysis confirm the hydraulic interconnection of the three aquifers mentioned above; it also was confirmed that the main source of recharge was provided by Ica River and evidences were found about the contribution of Pisco River in the recharge of Villacuri and Lanchas Aquifers.

Analysis of ${ }^{14} \mathrm{C}$ reveals that some wells are overexploited. All the results of ${ }^{3} \mathrm{H}$ analysis were out of range, so it was not useful for the conclusions of the study, and a new sampling of water is required; the reason of this out of range result should be the possible contamination of the samples with no environmental Tritium.

Keywords: Stable Isotopes, Aquifers, Hydrodynamics, World Meteorological Line, Evaporation

\section{Introduction}

Ica River Valley has a cultivable area of more than 30,000 Ha, and it is one of the most important areas of agricultural activity in Peru. In the valley, various products are grown for both local and foreign markets. In the last 15 years the production had such an increase that it gave rise to the over exploitation of the Ica Aquifer that contributes with $40 \%$ of the volume of water used in the agricultural activity, an exploitation that was evidenced by the accelerated decrease of the phreatic levels in the wells, as well as the notable increase in the salinity of groundwater, a trend that continues until now and it is the reason why several hydrological studies were carried out that served as a basis for proposing projects that contribute to the solution to these problems.

Ica River is one of the few rivers that flows along the coast of Peru, a desert area in which it almost never rains, the river rises in the zone of the sierra and empties into the Pacific Ocean, the river has a channel that passes through the middle of Ica Aquifer, on which agricultural zone is located; the flow of the river contributes with the remaining $60 \%$ of the volume of water used in agricultural activity and the irrigation system used mainly is by flood. Ica Aquifer is a free aquifer constituted in a matrix of alluvial terrain of the quaternary and is hydraulically connected to the aquifers of Villacuri and Lanchas; also, it is close to Pisco River that has a greater flow that could also contributes to the recharge of the aquifer.

In this context, the National Council of Science and Technology of Peru (CONCYTEC) through the Fund for Financing Science and Technology (FINCYT) financed an hydrological study of the area where the isotopic techniques were applied, which was carried out by the Institute Peruvian Nuclear Energy (IPEN) with the cooperation of the National Water 


\section{Macrothink}

Authority (ANA) in order to increase knowledge of the hydrodynamics of the aquifer and the water masses of Ica River Basin and to contribute to the solution of exploitation problems of Ica Aquifer and to increase of water supply to the valley.

\section{Background}

The valley of Ica was the object of several studies of hydrology since the 1950s, which supported the execution of works to increase the supply of water to the valley, having as results the regulation of lagoons in the high Andean area where Ica and Pisco Rivers are born and the water transfer from the Amazon Basin to the Pacific Ocean through tunnels and canals.

During 1995-1996, IPEN in cooperation with Lima Drinking Water and Sewerage Service (SEDAPAL) and the technical cooperation of the Isotope Hydrology Section of the International Atomic Energy Agency (IAEA) carried out a monthly rainwater sampling program for the analysis of stable isotopes ${ }^{18} \mathrm{O}$ and ${ }^{2} \mathrm{H}$ in the central coastal axis of Peru that included Rimac, Chillon Basins and upper river basin of Mantaro River in order to elaborate the Local Meteoric Water Line (LMWL) as part of the hydrological study of the Lima Aquifer, whose results are shown in Fig. 1; information used in the present study due to the lack of updated information of the study area. The central coastal-sierra axis referred to above is between 250 and $300 \mathrm{~km}$ away from Ica River Basin.

Also, during the periods 1989 - 1992 and 2012 - 2014 rainwater, springs and wells were sampled for analysis of Tritium in Rimac River Basin, whose results are shown in Table 1, which reveals that currently concentrations of environmental Tritium in rainwater are two Tritium Units ( $2 \mathrm{TU}$ ) with an error range of $\pm 0.5 \mathrm{TU}$, results that also serve as a reference for this report.

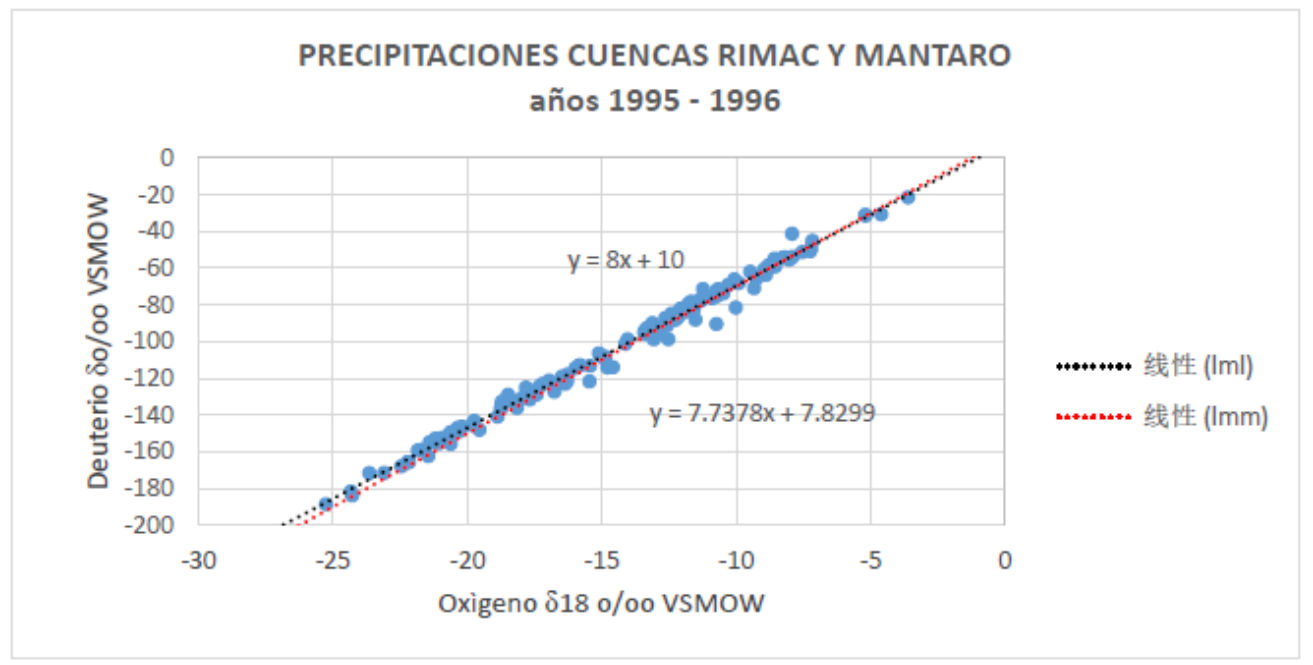

Figure 1. Global Meteorological Line (GMWL) and Local Meteoric Line (LMWL) on the central coastal axis of Peru

Source: Rojas R., Ruiz J.C. - IPEN, SEDAPAL Source of Graton tunnel waters, 2003 (Rojas \& Ruiz, 2002) 
Table 1. Tritium in rainwater in the Rimac, Chillon and Mantaro Basins in TU

\begin{tabular}{|c|c|c|c|c|c|c|}
\hline \multirow[t]{2}{*}{ Source Type } & \multicolumn{2}{|c|}{ CHILLÓN } & \multicolumn{2}{|c|}{ CHILLON-RIMAC-MANTARO } & \multicolumn{2}{|c|}{ RÍMAC } \\
\hline & $\begin{array}{c}\text { 1989-1992 } \\
\text { Average }\end{array}$ & $\begin{array}{c}\text { 2012-2014 } \\
\text { Average }\end{array}$ & $\begin{array}{c}1995 \\
\text { Average }\end{array}$ & $\begin{array}{c}1996 \\
\text { Average }\end{array}$ & $\begin{array}{c}\text { 1989-1992 } \\
\text { Average }\end{array}$ & $\begin{array}{c}\text { 2012-2014 } \\
\text { Average }\end{array}$ \\
\hline $\begin{array}{l}\text { Groundwater } \\
\text { (Wells) (pozos) }\end{array}$ & 3.17 & 1.04 & & & 3.15 & 0.9 \\
\hline Rainwater & 5.0 & & 3.8 & 3.7 & 5.0 & \\
\hline $\begin{array}{l}\text { Rainwater } \\
\text { (obtained from } \\
\text { springs in } \\
\text { and } \\
\text { Basins) }\end{array}$ & & 2.0 & & & & 2.0 \\
\hline
\end{tabular}

Source: Rojas R., Mamani E., Peña F., Charca M., Alva E. - IPEN, SEDAPAL, INGEMMET Report "Update of the hydrological study of the Lima aquifer " (in preparation) (Rojas et al.,).

\section{Hydrogeological Framework of the Study Area}

\subsection{Hydrology}

Ica River Basin has the following hydrological characteristics (Peña et al., 2010; Chamorro, 2016):

Area of the basin:

\section{$7,188 \mathrm{Km} 2$}

Altitude:

0 to 4,600 meters above sea level

Aquifer area:

$30,700 \mathrm{Ha}$

Altitude:

0 to 500 meters above sea level

Precipitation in the area of the aquifer: $20 \mathrm{~mm} /$ year (estimated)

Average precipitation in basin: $380 \mathrm{~mm} /$ year in the range of altitudes of 2000 to 3200 meters above sea level

Average precipitation in basin: $645 \mathrm{~mm} /$ year in the range of altitudes of 3200 to 3800 meters above sea level

Average precipitation in basin: $700 \mathrm{~mm} /$ year in the range of altitudes of 3800 to 4600 meters above sea level

Rainfall regime:

3 to 4 months of rain and 8 to 9 months of low water

Temperature range $\left({ }^{\circ} \mathrm{C}\right.$ ): $\quad 21$ to 34 (in zones of the aquifer)

Temperature range $\left({ }^{\circ} \mathrm{C}\right): \quad 6$ to 14 (in mountain areas)

Average relative humidity: $\quad 70 \%$ (coast) and 60\% (highland) 
Average annual runoff:

Average infiltration:

Evaporation:

Potential evapotranspiration:

Actual evapotranspiration:
$77.2 \mathrm{~mm} /$ year

$64.2 \mathrm{~mm} /$ year

varies between 1154 to $1970 \mathrm{~mm} /$ year

varies between 1319 to $1229 \mathrm{~mm} /$ year

varies between 780 and $1142 \mathrm{~mm} /$ year

\subsection{Hydrogeology}

The studies carried out by INGEMMET (Peña et al., 2010) indicate that Ica River Basin has diverse hydrogeological units constituted by igneous, sedimentary and metamorphic rocks that have chronological ranges between the Proterozoic to the Quaternary. The basin receives contributions from the Choclococha, Orcococha and Ccaracocha lagoons through channels and a trans-Andean tunnel, which transports waters from Pampas River basin that belongs to the Amazon basin to the Pacific basin where Ica aquifer is located.

Ica Aquifer has a length of the order of $60 \mathrm{~km}$ and a width that varies between 3 to $15 \mathrm{~km}$. It is bounded on the east and north by hills and another ones that constitute Andean foothills, on the west by the sea, the Great Tablazo of Ica and Bandera and Media Luna hills; to the north by Pisco River Basin, and to the south by Choros, San Nicolás and Yamanaque Rivers and Grande River. Villacuri and Lanchas Aquifers are located northeast of Ica aquifer and the three aquifers have the same matrix and geological formation that corresponds to a free porous aquifer.

The aquifers are constituted by fluvial and alluvial deposits of boulders, blocks, sand and gravel of the quaternary with a variable thickness; In the North sector, the aquifer lies on a waterproof basement constituted by intrusive igneous rocks of the coastal batholith, such as gneiss and micro conglomerates, and sedimentary and volcanic sedimentary rocks of Pisco, Guaneros, Hualhuani and Quilmana formations in the Central and Southern sectors.

The coastal zone of the basin is crossed by a regional system of longitudinal parallel faults and transverse to the coast, and in the Andean area a system of longitudinal folds from southeast to northeast direction and longitudinal faults mostly sub vertical that affects the sedimentary units and intrusive of the coast's batholith.

\section{Methodology}

Based on the hydrogeological information of the area, samples from the 31 tubular wells which aquifer groundwater samples were previously obtained were selected, as well as the springs, lagoons and river points from which the water samples were extracted. Likewise, a sampling schedule was drawn up during the 3 years of the project, trying to be spatially and temporally representative of the bodies of water that intervene in the study area.

For this purpose, samples of the following water masses were obtained: groundwater from the Ica aquifer, river waters, lagoons and springs from the Ica Valley; Ica Aquifer samples were obtained by pumping 31 of the more than 1,500 wells that operate in the study area, which is 
estimated to provide a first approximation of the aquifer's hydrodynamics, samples were also obtained from 2 rivers, 5 lagoons and 2 springs from Ica and Pisco river basins. Sampling was carried out in 5 campaigns carried out during the years 2014 to 2016 in periods of rain and low water, by collecting a total of 189 samples, that were analyzed for stable isotope concentrations of Oxygen and Hydrogen: ${ }^{18} \mathrm{O},{ }^{2} \mathrm{H}$, as well as radioactivity analysis of ${ }^{3} \mathrm{H},{ }^{14} \mathrm{C}$ and stable isotope concentration 13C.

Isotope analyzes were carried out by the Isotope Tracer Technologies Inc. in Waterloo, Canada.

\section{Field Work}

The fieldwork was carried out by the staff of IPEN and from the National Water Authority (ANA) and consisted of taking water samples from wells, springs, lagoons and rivers in 5 campaigns during the years 2014 to 2016 (Chamorro, 2016), already referred above. The samples were stored in the facilities of IPEN and sent to the laboratory for analysis of ${ }^{18} \mathrm{O}$ of the Oxygen isotopes, ${ }^{2} \mathrm{H}$ (Deuterium) and ${ }^{3} \mathrm{H}$ (Tritium) of the Hydrogen, as well as ${ }^{13} \mathrm{C}$ and ${ }^{14} \mathrm{C}$ concentrations of the organic Carbon dissolved in the masses of Water.

Results of ${ }^{18} \mathrm{O}$ and ${ }^{2} \mathrm{H}$ stable isotopes analysis are plotted in figures $\mathrm{F} 1$ to $\mathrm{F} 10$, those of ${ }^{13} \mathrm{C}$ as well as the results of analysis of radioactive isotopes ${ }^{3} \mathrm{H}$ and ${ }^{14} \mathrm{C}$ are found in the Annex.

The sampling campaigns did not include samples of rainwater, due to limitations of time required to have statistically reliable results, in replacement samples were obtained from springs located in the upper basin of Ica and Pisco Rivers, (area between Ica and Pisco) that partially compensated this lack, considering that they represent the average of rainwater of recent years, and by adding, for the purposes of the present study the results of isotope analysis of rain samples collected by the IPEN in 1995 and 1996 within the framework of an IAEA technical cooperation project, and analyzes carried out in IAEA laboratories, Isotopic Hydrology Section, Vienna, Austria (Rojas \& Ruiz, 2002; Rojas et al., 2003).

Below, study areas are shown with the sampling points in the aquifers of Ica, Villacuri and Lanchas, as well as lagoons, rivers and springs of the upper basin of Ica River. 


\section{Macrothink \\ Environmental Management and Sustainable Development \\ ISSN 2164-7682 \\ 2020, Vol. 9, No. 2}

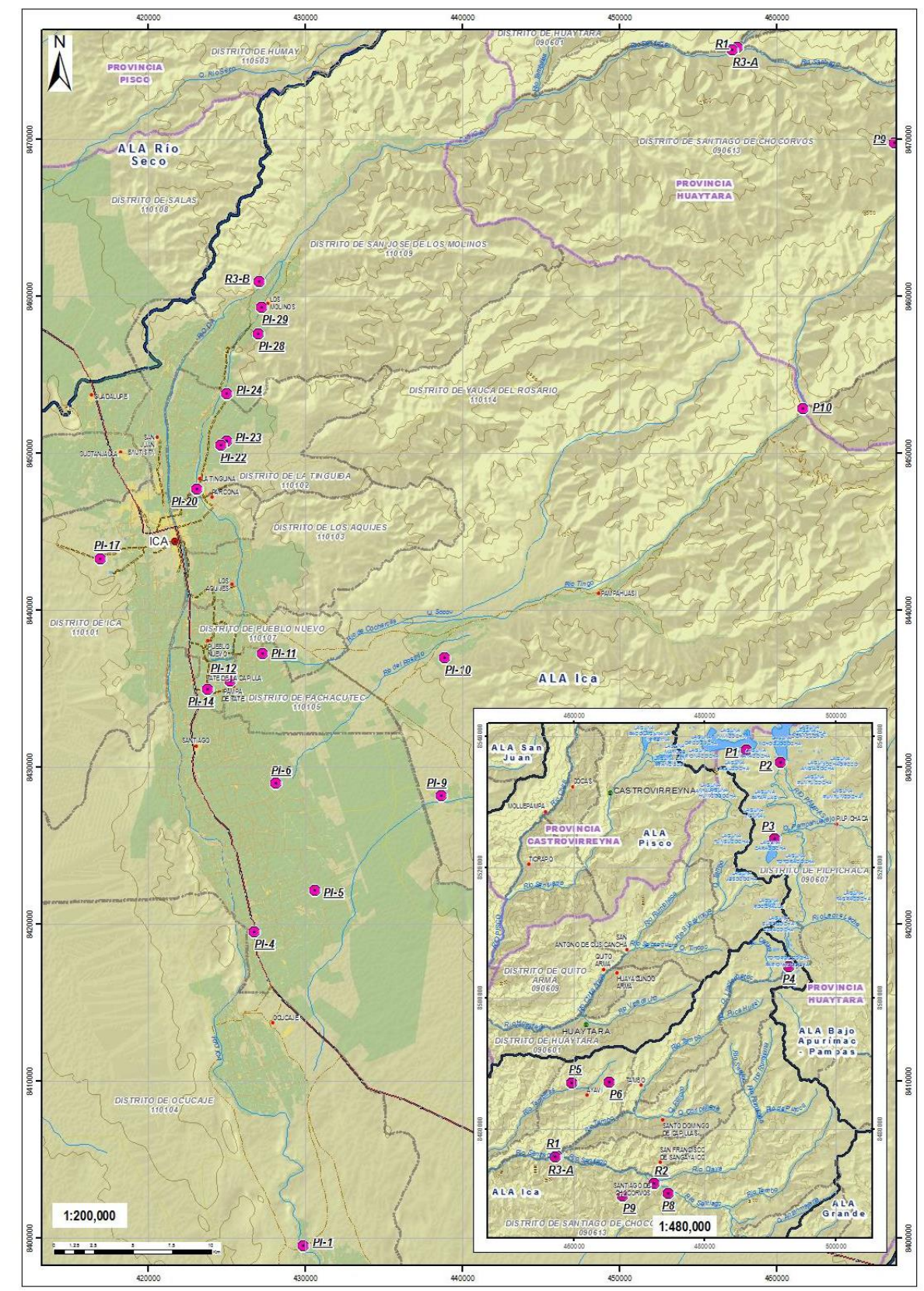

Figure 2. Location of the sampling points in the upper watershed of the study area 


\section{Macrothink \\ Environmental Management and Sustainable Development \\ ISSN 2164-7682 \\ 2020, Vol. 9, No. 2}

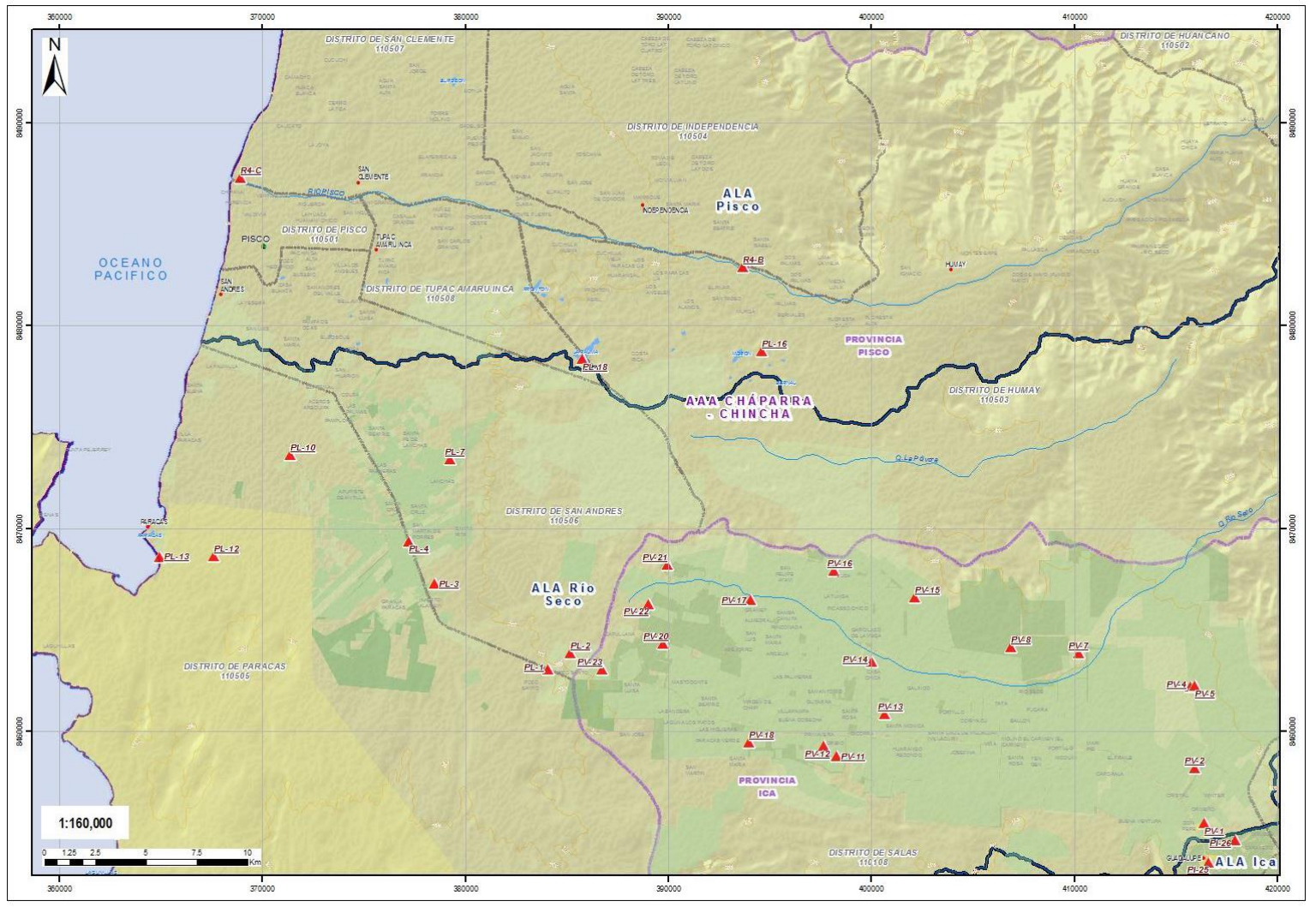

Figure 3. Location of the sampling points in Villacuri and Lanchas 


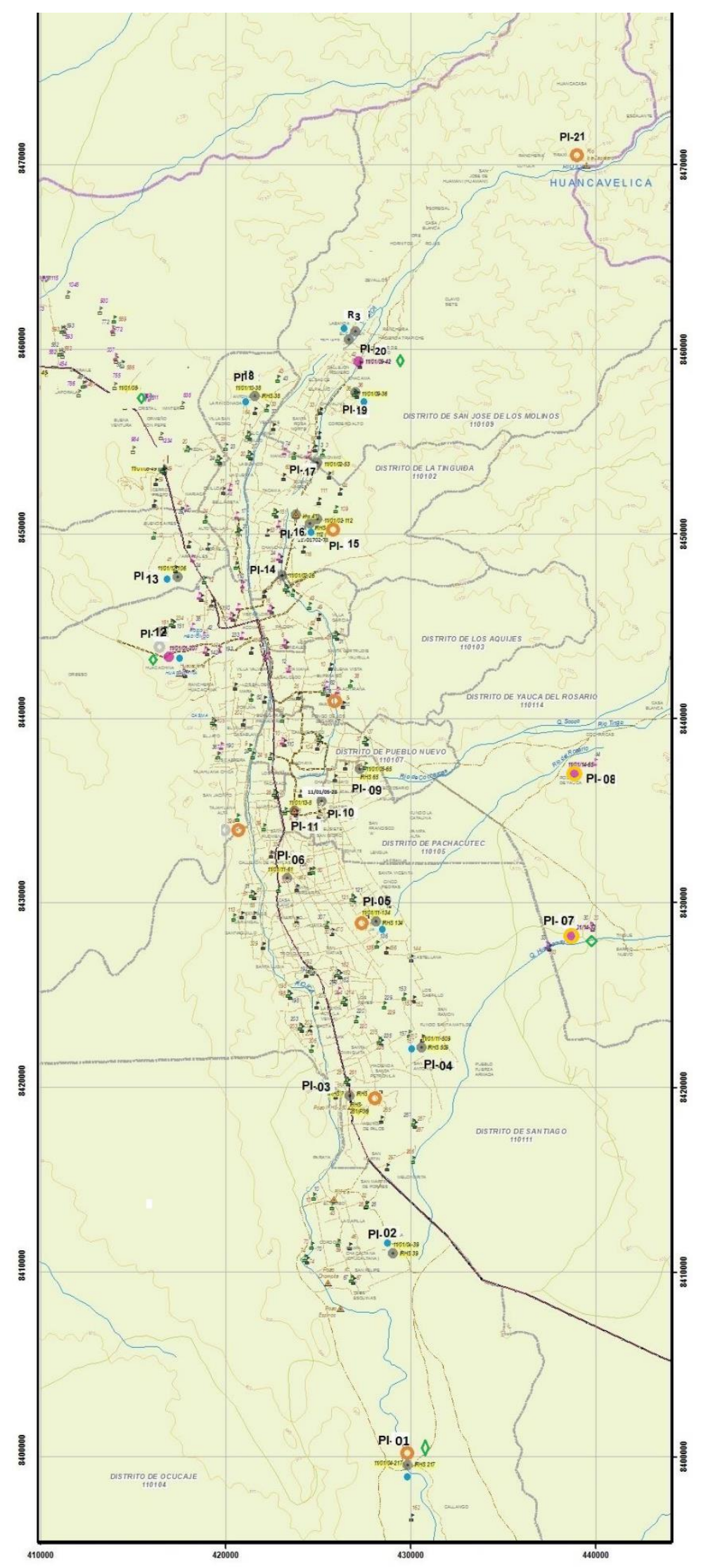

Figure 4. Location of the sampling points in the Ica Valley 


\section{Macrothink}

\section{Results}

\subsection{Stable Isotopes}

Isotope analysis results are plotted for each of the 5 sampling campaigns carried out during the years 2014, 2015 and 2016, which are detailed below:

\subsubsection{Campaign 1. Ipper Basin of Rivers Ica and Pisco - June 2014}

The results are plotted in Fig. 5 and correspond to the sampling campaign in the high Andean area of the basin, where the concentrations " $\partial "$ of ${ }^{18} \mathrm{O}$ (Oxygen-18) and ${ }^{2} \mathrm{H}$ (Deuterium) of lagoons and springs are shown. From the upper basin of Ica and Pisco Rivers, the graph shows that the springs are aligned with the Global Meteorological Line (GML) which, as already stated, is quite similar to the Local Meteoric Line (LML), which validates the hypothesis that these water bodies represent average rainfall for several years.

The lagoon waters are aligned in the typical "Evaporation Line" that characterizes the water masses exposed to the atmosphere and consequently subject to evaporation, both in low altitude areas such as the aquifer, but especially in areas located at high altitude above sea level (4,500 m.o.s.l. on average), where the reduced atmospheric pressure helps to increase evaporation, which translates into the increase of isotopic concentrations or isotopic enrichment with respect to rainwater.

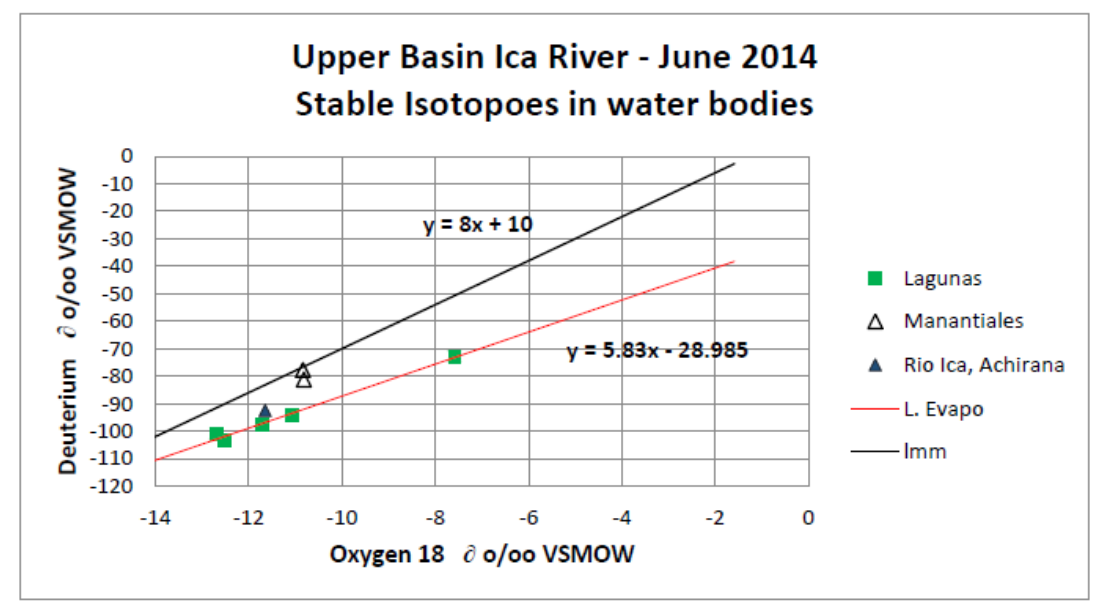

Figure 5. Concentrations of ${ }^{2} \mathrm{H}$ and ${ }^{18} \mathrm{O}$ in Ica River and springs and lagoons of the upper basin

The most extreme case of evaporation is found in the sample called "artificial lagoon" that is considered to have no greater influence due to the reduced volume stored.

Ica River rises in these high Andean lakes (more than 4,000 meters over sea level) and recharges the aquifers of Ica, Villacuri and Lanchas, but the results shown in this graph are from the area of Achirana (522 m.o.s.l) which is located on the coast at start of the aquifer, and it is noted that it is more aligned with the evaporation line, which reveals the evaporation 


\section{Macrothink}

effect suffered by the lagoons in the high Andean area, despite the effect of the contribution of springs and tributaries downstream during their flow To the sea.

On the other hand, the sample from Ica River in Achirana area was collected in June, which corresponds to the dry season of the sierra, where there are no rainfalls, consequently it has isotope characteristics similar to those of the lagoons of the Choclococha system, which reveals that in this period Ica Valley is using the dammed waters and consequently remnants of evaporation in the lagoons of the upper basin.

\subsubsection{Campaign 2. Upper Basin and Aquifers - October 2014}

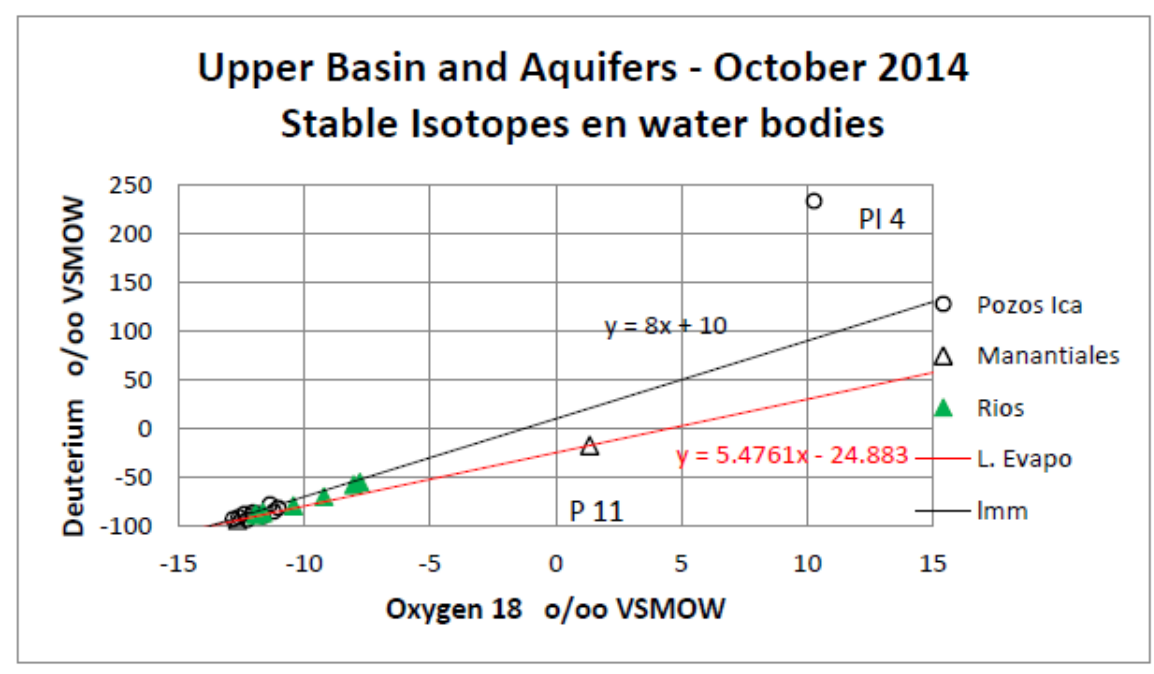

Figure 6. Concentrations of ${ }^{2} \mathrm{H}$ and ${ }^{18} \mathrm{O}$ in wells of the Ica aquifer and springs and rivers of the upper basin

The results are plotted in Fig. 6 and 7, and correspond to samples from springs and rivers in the upper basin and wells of the Ica aquifer, where it can be seen that there are 2 samples that have extreme values of isotopic concentrations that are shown in Fig. 6.

Well PI 4. Indicates extreme evaporation, the values of isotope concentrations are out of range for groundwater samples, which is why the origin of the sample and its custody should be reviewed until it is sent to the laboratory.

Spring P 11. Sample that corresponds to Chulco Chico spring, indicates a quite high evaporation that does not correspond to a spring, but possible if the sample comes from standing water of the spring.

In Fig. 7 the same results are plotted but in a range of concentrations that exclude the extreme values referred to above, where it can be seen that the isotopic concentrations of Ica River in Achirana did not change significantly compared to the previous season, the aquifer of Ica has, from the isotopic point of view, a wide spectrum of water masses that compose it, some of which are more enriched isotopically with respect to the waters of the Ica River in Achirana, which is expected by the evaporation to which they are subjected during the irrigation before 


\section{Macrothink}

infiltrating the aquifer, enrichment that is estimated to be increased by the repeated process of: pumping water from the wells - irrigation - infiltration - pumping, which takes place in the fields of Ica Valley. Another possible source of these isotopically enriched waters is the infiltration of streams and streams located at medium altitudes such as Tingo, Tambo and Santiago, which have isotopically enriched waters according to the analyzes.

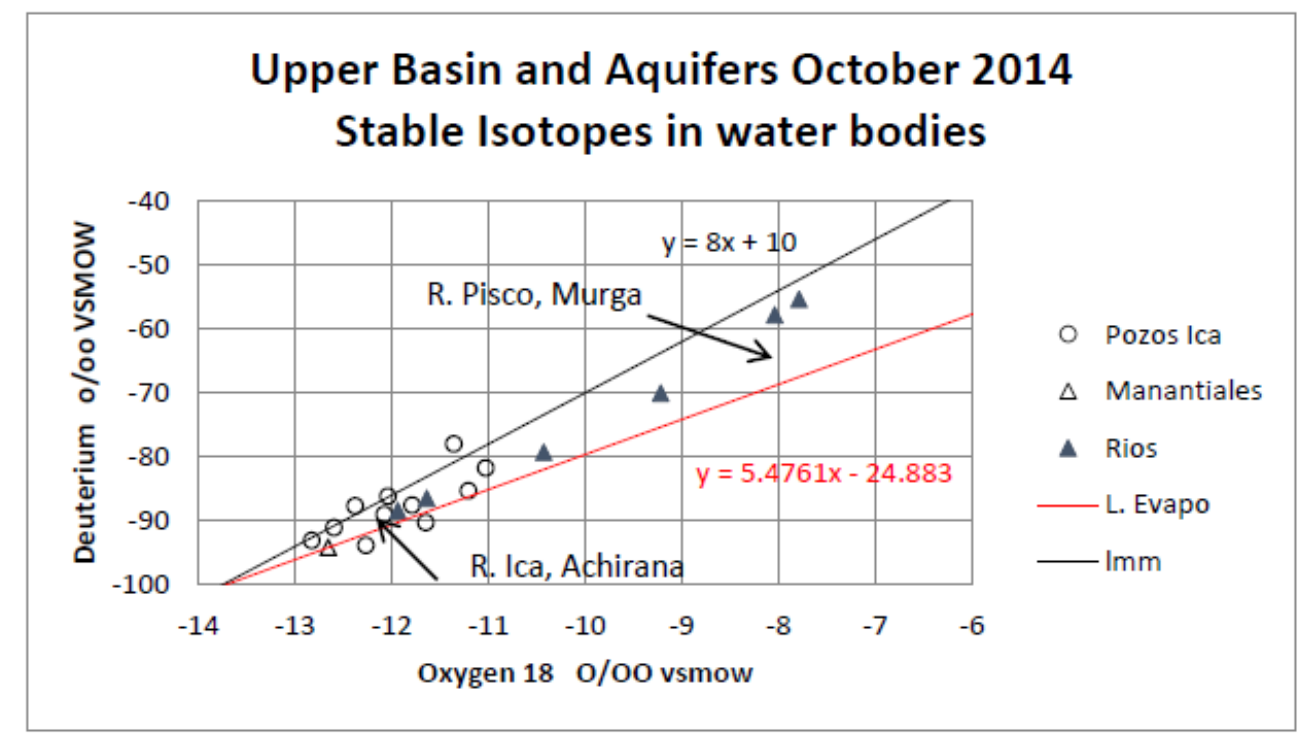

Figure 7. Concentrations of ${ }^{2} \mathrm{H} y{ }^{18} \mathrm{O}$ in wells of Ica Aquifer, streams and rivers of upper basin

But also in the aquifer the presence of impoverished water masses isotopically, which reveals a different origin to the infiltration of the Ica river and its tributaries, the isotopic characteristics of these water masses, indicate that they come from rainwater occurring in Andean high areas that were not exposed to evaporation, the possible infiltration of rain in high Andean areas could be the origin of these water masses, also, the possible infiltration of Pisco river or one of its tributaries could be another origin of these masses of isotopically impoverished water.

\subsubsection{Campaign 3. Upper Basin and Aquifers - April 2015}

The results are shown in Fig. 10, where it can be seen that Ica River at the Achirana intake has been depleted isotopically compared to previous seasons, which reveals that it does not come from lagoon waters, its origin is the runoff from Andean high rainfalls very little affected by evaporation, which is consistent with the period in which the sampling was carried out that corresponds to the rainy season of the sierra when the lagoons do not contribute water to Ica River because the outlet gate is closed. The waters of the aquifer maintain the great dispersion of its isotopic concentrations with respect to the waters of Ica River in Achirana, which shows the diversity of its origin, such as those evaporated by irrigation, and the possible contribution of the tributary rivers of the Ica river. 


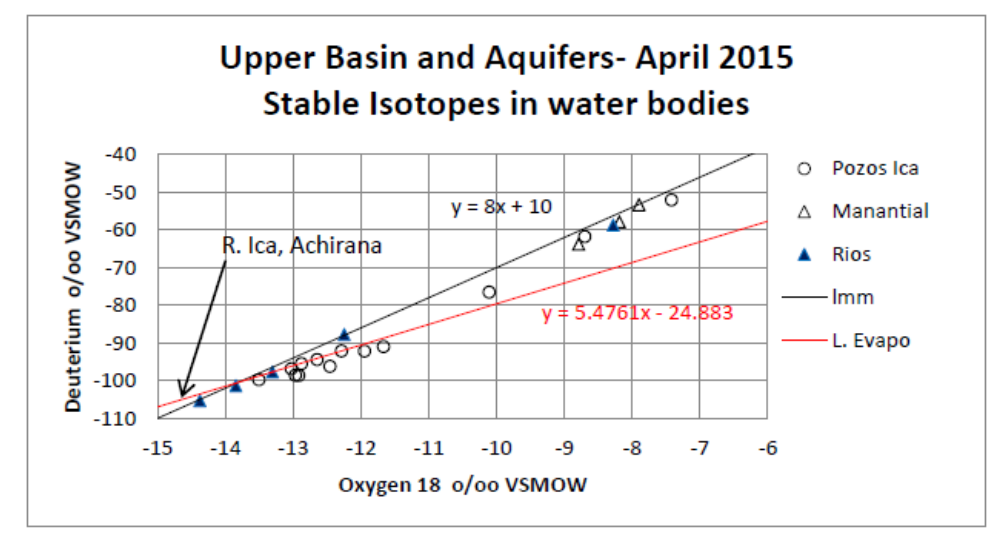

Figure 8. Concentrations of ${ }^{2} \mathrm{H}$ and ${ }^{18} \mathrm{O}$ in wells of Ica aquifer, springs and rivers of the upper basin

But also in the aquifer the presence of impoverished water masses isotopically, which reveals a different origin to the infiltration of the Ica river and its tributaries, the isotopic characteristics of these water masses, indicate that they come from rainwater occurring in Andean high areas that were not exposed to evaporation, the possible infiltration of rain in high Andean areas could be the origin of these water masses, also, the possible infiltration of the Pisco river or one of its tributaries could be another origin of these masses of isotopically impoverished water.

\subsubsection{Campaign 4. Upper Basin and Aquifers - November 2015}

The results are shown in Fig. 9, where it can be seen that the Ica river in Achirana is isotopically enriched, which reveals that it comes from the system of repressed and regulated lagoons in Choclococha and others in the high Andean zone, the waters of the Ica Aquifer, maintains the same dispersion characteristics with respect to the waters of the Ica River in Achirana in previous seasons, which indicates the influence of various sources of recharge in addition to that of Ica river.

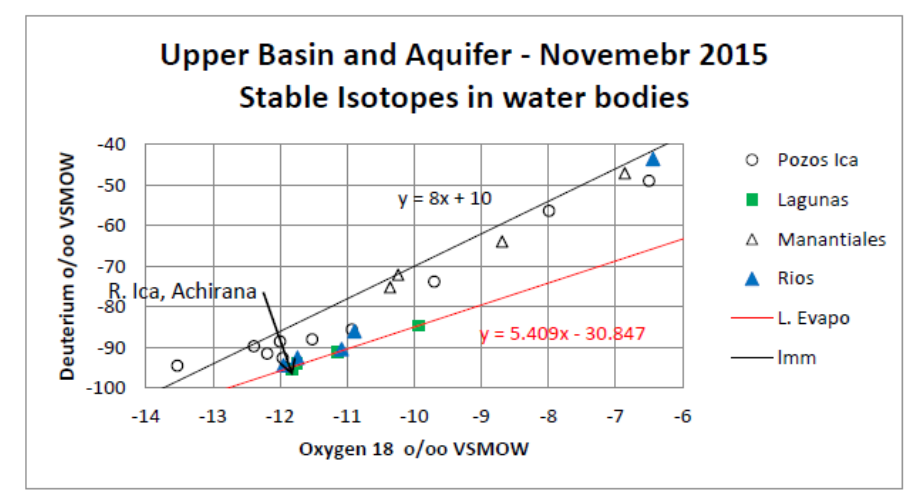

Figure 9. Concentrations of ${ }^{2} \mathrm{H}$ and ${ }^{18} \mathrm{O}$ in wells of Ica Aquifer and springs, lagoons and rivers of the upper basin 


\section{Macrothink}

\subsubsection{Campaign 5. Upper Basin and Aquifers - June 2016}

The results are shown in Fig. 10, where the isotopic concentrations of water from the wells of Ica, Villacuri and Lanchas Aquifers, as well as lagoons, rivers and springs of the high Andean zone have been plotted, in which can be seen that the dispersion of isotopic concentrations of the wells of Ica Aquifer is maintained, those ones enriched isotopically with respect to waters of Ica River in Achirana, they are undoubtedly from infiltrated waters of Ica river and waters reused in the pumping and irrigation of crop fields; the isotopically impoverished ones come undoubtedly from sources other than Ica River. Villacuri and Lanchas aquifers are grouped in an area of isotopically more impoverished waters, at least during periods of low water when the samples were taken, which reveals that their source of recharge is not Ica river; this source could be Pisco River and / or rainwater masses infiltrated in high Andean areas that reach the aquifer through a system of deep circulation through permeable rocks and / or system of geological faults in the area.

The lagoons and rivers maintain their range of dispersion of isotopic concentrations of previous campaigns that reveal their contribution in recharging Ica, Villacuri and Lanchas Aquifers.



Figure 10. Concentrations of ${ }^{2} \mathrm{H}$ and ${ }^{18} \mathrm{O}$ in wells of aquifers of Ica, Villacuri and Lanchas, and springs, lagoons and rivers of the upper basin

\subsection{Radioactive Isotopes}

\subsubsection{Tritium}

Tritium values shown in the Annex are out of range for the geographical location of Peru and the current time. The values of Tritium in rainwater and, with greater reason, the subterranean ones, as previously stated, should not exceed $2.0 \pm 0.5 \mathrm{TU}$, however, all the values reported by the laboratory show higher values, consequently the calculations of ages resulted in values negative, which is why the age of the water calculated based on reported Tritium activity 
values should be discarded. The Tritium that has a half-life of 12.4 years is the most suitable for studies of non-fossil aquifers such as those of the Ica Valley, so the absence of reliable results of the activity of this isotope, prevents the determination of residence times of groundwater and consequently of its recharge capacity.

\subsubsection{Carbon 14}

The results of ${ }^{14} \mathrm{C}$ are shown in the Annex and are in PCM units (percentage of modern carbon) whose pattern is provided by international convention by the NIST Office of US Standards.

The ages or residence times of the groundwater calculated based on ${ }^{14} \mathrm{C}$ data were adjusted with data of ${ }^{13} \mathrm{C}$ concentrations, following the method of Dr. Roberto Gonfiantini (Mook, 2000), which are indicated in the following table. Given that the average life of ${ }^{14} \mathrm{C}$ is 5,700 years, the error range of this methodology is of the order of one hundred years, not very appropriate for the aquifers under study, for which the ages resulting from the calculations shown are referential.

Table 2. Age of groundwater in aquifers of Ica Valley

\begin{tabular}{|l|l|l|l|l|l|l|}
\hline AGE OF GROUNDWATERS & Code & C14 -PMC & C13 & $\begin{array}{l}\text { Age, reference } \\
\text { to C14 }\end{array}$ & Tritium & $\begin{array}{l}\text { Age, reference } \\
\text { to H3 }\end{array}$ \\
\hline LOCATION & Sample & $(\%)$ & o/oo & (years) & (UT) & (years) \\
\hline & P2 & 73.8 & -7.7 & 467.9 & 9.8 & -28.2 \\
\hline L. Choclococha & P8 & 98.15 & -13.3 & 66.1 & 9.1 & -26.9 \\
\hline Manantial Q. Aguacha & R3A & 92.07 & -11.1 & 228.9 & 14.1 & -34.7 \\
\hline River Ica (Challaca) & PI 2 & 92.2 & -14.4 & 292.2 & 5.9 & -19.2 \\
\hline Pozo Acuifero Ica & PI 8 & 74.23 & -11.7 & 701.5 & 6.1 & -19.8 \\
\hline Pozo Acuifero Ica & PI 10 & 78.75 & -10.6 & 540.5 & 5.7 & -18.6 \\
\hline Pozo Acuifero Ica & PI 14 & 89.93 & -14.7 & 380.3 & 5.0 & -16.3 \\
\hline Pozo Acuifero Ica & PI 17 & 75.59 & -13.5 & 774.0 & 14.6 & -35.3 \\
\hline Pozo Acuifero Ica & PI 26 & 98.73 & -12.4 & 42.4 & 9.2 & -27.1 \\
\hline Pozo Acuifero Ica & PI 28 & 96.49 & -11.6 & 108.4 & 11.3 & -30.7 \\
\hline Pozo Acuifero Ica & PV1 & 99.11 & -13.6 & 32.7 & 4.8 & -15.5 \\
\hline Pozo Acuifero Villacuri & PV7 & 62.47 & -12.4 & 987.8 & 7.3 & -23.0 \\
\hline Pozo Acuifero Villacuri & PV7 & -11 & 679.8 & 8.0 & -24.6 \\
\hline Pozo Acuifero Villacuri & PV 15 & 73.25 & -13 & 1242.5 & 9.4 & -27.5 \\
\hline Pozo Acuifero Villacuri & PV 17 & 47.88 & -8.9 & 669.2 & 4.1 & -12.7 \\
\hline Pozo Acuifero Villacuri & PV 20 & 65.45 & -10.4 & 1035.1 & 5.3 & -17.3 \\
\hline Pozo Acuifero Villacuri & PV 23 & 34.58 & -9.5 & 925.9 & 9.2 & -27.1 \\
\hline Pozo Acuifero Lanchas & PL 2 & 44.86 & -13.2 & 1302.5 & 17.3 & -38.3 \\
\hline Pozo Acuifero Lanchas & PL12 & 31.61 & & & & \\
\hline
\end{tabular}

The results of the ${ }^{14} \mathrm{C}$ analysis in wells PV15, PV17, PV20, PV23, PL2 and PL12 indicate 
that very old waters are being extracted, which means that they have limited recharge capacity. On the other hand, wells P8, PI2, PI14, PI26, PI28, PV1, have good recharge capacity, the other wells are in an intermediate situation.

\section{Discussion of Results}

Due to the location of Ica River and Ica Aquifer, the hydrogeological characteristics of the aquifer, it is considered that Ica River recharges the aquifer, consequently the isotopic characteristics between these water bodies are estimated to be similar, on the other hand, the evaporation that has place in high Andean areas such as those of the lagoons of the Choclococha system, determine that the waters of the Ica river from its source is marked by the isotopic enrichment of ${ }^{2} \mathrm{H}$ and ${ }^{18} \mathrm{O}$, as confirmed by the results of analysis of concentrations of these stable isotopes, Concentrations that must be increased by another process of evaporation that takes place in the fields by the irrigation of the plantations, when part of these water masses infiltrate the subsoil recharging the aquifer with water remaining from the evaporation.

\subsection{Ica Aquifer}

The results of isotope analysis show that part of the water in the wells are isotopically enriched, which reveal that they come from the infiltration of Ica River and from the reuse of water masses infiltrated to the aquifer by irrigating the fields with water extracted from the aquifer by pumping of the wells.

The results of the analysis also show the presence of an important group of wells that have isotopically more impoverished waters than waters of Ica River at Achirana intake, which suggests that there are other sources of recharge of the aquifer besides the Ica river, which could be seepage of tributaries of Ica or Pisco River in high Andean areas, another possible source would be the Pisco river that has a nearby basin and is born in the high Andean zone that has isotopically impoverished water characteristics typical for the altitude above sea level. That is its source of recharge, also because it has no gaps that are part of its basin.

It is also possible that the infiltration of rain in permeable lands in high zones participate in the recharge of the aquifer, through a deep flow through geological faults and / or porous rocks whose presence was detected in the studies carried out by INGEMMET (Peña et al., 2010).

\subsection{Villacuri Aquifers and Lanchas}

In Villacuri and Lanchas, there are only samples of a campaign that was carried out in June 2016 (dry period in the mountains), the results of isotopic analysis indicate that only a small part of the wells come from the river filtrations In Ica, most of the wells are characterized by their isotopic impoverishment, consequently they cannot come from Ica River which, as already mentioned, from its source is marked by the isotopically enriched, the recharge of these aquifers may come from the same sources of Ica Aquifer and / or tributaries of the Ica and Pisco rivers that infiltrate high Andean areas, or the same Pisco River infiltrated in high Andean areas, water masses that are characterized by the isotopic impoverishment of ${ }^{2} \mathrm{H}$ and 
${ }^{18} \mathrm{O}$.

\section{Conclusions}

The following conclusions regarding to Villacuri and Lanchas Aquifers should be considered preliminary because there is not enough isotopic analysis results:

a. The isotopic analyzes verify the hydraulic interconnection that exists between the Ica River and the wells of the aquifers, the isotopic analyzes also indicate that there is evidence of a hydraulic interconnection between the aquifers and the Pisco River and / or its tributaries.

b. The aquifers of the valley of Ica, Villacuri and Lanchas have as a source of recharge the infiltration of the Ica river and other sources that possibly includes the Pisco River; it is required to expand the water sampling to have definitive conclusions.

c. The absence of reliable Tritium values does not allow to determine the residence time of aquifer waters, however, the results of analysis of ${ }^{14} \mathrm{C}$ and ${ }^{13} \mathrm{C}$ indicate that in some wells (detailed in Section 7.2), old waters are being extracted, which reveals that such wells have little capacity of recharge.

\section{Acknowledgement}

This study was financed by National Council of Science and Technology of Peru (CONCYTEC) through the Research Fund for Science and Technology (FINCYT) and was carried out by the Institute Peruvian Nuclear Energy (IPEN) in cooperation with the National Water Authority (ANA), which gave all the facilities for performing the activities of sampling and support by means of its staff.

\section{References}

Peña, F., Sánchez, M., \& Pari, W. (2010). Hidrogeología de la cuenca del rio Ica. INGEMMET. Lima.

Mook, W. G. (2000). Environmental Isotopes in the Hydrological Cycle. UNESCO/IAEA, Groningen, Holland.

Rojas, R., Mamani, E., Peña, F., Alva, W., \& Charca, M. Actualización del conocimiento del acuífero costero del Rímac y Chillón. IPEN - SEDAPAL - INGEMMET - Lima (in preparation).

Chamorro, C. (2016). Estado situacional del Proyecto "Evaluación del potencial de recursos hídricos subterráneos del Perú". IPEN, Lima.

Rojas, R., \& Ruiz, J. C. (2002). Origen de aguas del túnel Graton. IPEN - SEDAPAL. Lima.

Rojas, R., Paredes, M., \& Campos, J. (2003). Estudio Hidroquímico e Isotópico del lago Titicaca. IPEN - PELT - IBTEN. Lima. 


\section{Macrothink}

Environmental Management and Sustainable Development

ISSN 2164-7682

2020, Vol. 9, No. 2

\section{Appendix}

Results of Isotopic Analysis of Carbon 14 and Carbon 13

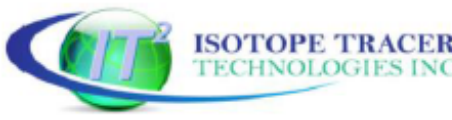

Client: Instituto Peruano de Energia Nuclear

Address: Av. Canada 1470, San Borja Lima, Peru

Tel: 4885050 ext. 225

Attn: Gerardo Maghella

E-mail: gmaghella@ipen.gob.pe

File Number: $\quad \underline{160185}$

\begin{tabular}{|c|c|c|c|c|c|c|c|c|c|}
\hline$\#$ & Sample ID & Collect: & & Sample \# & Sample Name (local) & Location & $E^{3} H$ & Result & \pm 10 \\
\hline & & Date & Time & & & & & & \\
\hline 1 & P1 & $2016-05-23$ & $17: 10$ & 38718 & Laguna Orcococha & Castrovirreyna & $\mathrm{x}$ & 12.1 & 1.2 \\
\hline 2 & P2 & $2016-05-23$ & $17: 50$ & 38719 & Laguna Choclococha & Castrovirreyna/Huatytara & $\mathrm{x}$ & 9.8 & 1.0 \\
\hline 3 & P3 & $2016-05-24$ & $7: 20$ & 38720 & Laguna Ccaracocha & Huaytara & $\bar{x}$ & 14.0 & 1.3 \\
\hline 4 & P5 & $2016-05-24$ & $13: 40$ & 38721 & Manantial Chaulisma & Huaytara & $x$ & 10.1 & 1.0 \\
\hline 5 & P8 & $2016-05-24$ & $18: 00$ & 38722 & Manantial Qda. Aguacha(Santiago) & Huaytara & $x$ & 9.1 & 1.0 \\
\hline 6 & R1 & $2016-05-25$ & $8: 22$ & 38723 & Rio Tambo & Huaytara & $\mathrm{x}$ & 10.4 & 1.1 \\
\hline 7 & R2 & $2016-05-25$ & $8: 00$ & 38724 & Rio Santiago & Huaytara & $\mathrm{x}$ & 7.9 & 0.9 \\
\hline 8 & R3-A & $2016-05-25$ & $8: 25$ & 38725 & Rio Ica (Challaca) & Huaytara & $\mathrm{x}$ & 14.1 & 1.3 \\
\hline 9 & R4-B & 2016-05-19 & $18: 30$ & 38726 & Río Pisco (Pte. Murga) & Pisco & $\mathrm{x}$ & 16.9 & 1.5 \\
\hline 10 & $\mathrm{Pl}-2$ & $2016-05-27$ & $13: 55$ & 38727 & $11 / 01 / 04-0296$ & ICa & $x$ & 5.9 & 1.0 \\
\hline 11 & $\mathrm{Pl}-3$ & $2016-05-27$ & $14: 30$ & 38728 & $11 / 01 / 04-0039$ & Ica & $x$ & 6.7 & 1.1 \\
\hline 12 & PI-5 & $2016-05-27$ & $15: 00$ & 38729 & $11 / 01 / 11-0509$ & Ica & $\mathrm{x}$ & 5.6 & 0.9 \\
\hline 13 & $\mathrm{Pl}-8$ & $2016-05-27$ & $7: 55$ & 38730 & $11 / 01 / 14-30$ & ICa & $x$ & 6.1 & 0.9 \\
\hline 14 & $\mathrm{Pl}-10$ & $2016-05-27$ & $7: 00$ & 38731 & $11 / 01 / 14-65$ & Ica & $\mathrm{x}$ & 5.7 & 0.9 \\
\hline 15 & $\mathrm{Pl}-13$ & 2016-05-27 & $8: 50$ & 38732 & $11 / 01 / 05-70$ & Ica & $\mathrm{x}$ & 5.7 & 0.9 \\
\hline 16 & $\mathrm{Pl}-14$ & $2016-05-22$ & $8: 40$ & 38733 & $11 / 01 / 13-8$ & ICa & $\mathrm{x}$ & 5.0 & 0.9 \\
\hline 17 & Pl-15 & $2016-05-27$ & $10: 20$ & 38734 & $11 / 01 / 03-77$ & Ica & $x$ & 5.5 & 0.8 \\
\hline 18 & $\mathrm{Pl}-16$ & $2016-05-26$ & $16: 25$ & 38735 & $11 / 01 / 01-431$ & ICa & $x$ & 4.0 & 0.6 \\
\hline 19 & Pl-17 & $2016-05-26$ & $15: 30$ & 38736 & $11 / 01 / 01-207$ & ICa & $x$ & 14.6 & 1.2 \\
\hline 20 & Pl-22 & $2016-05-26$ & $8: 22$ & 38737 & $11 / 01 / 02-73$ & Ica & $\mathrm{x}$ & 4.5 & 0.6 \\
\hline 21 & PI-24 & $2016-05-26$ & $9: 15$ & 38738 & $11 / 01 / 02-53$ & Ica & $x$ & 5.1 & 0.7 \\
\hline 22 & PI-25 & $2016-05-26$ & $14: 50$ & 38739 & $11 / 01 / 10-49$ & Ica & $\mathrm{x}$ & 9.5 & 0.9 \\
\hline 23 & Pl-26 & $2016-05-26$ & $12: 20$ & 38740 & $11 / 01 / 10-20$ & Ica & $\mathrm{x}$ & 9.2 & 0.8 \\
\hline 24 & Pl-28 & $2016-05-26$ & 9:50 & 38741 & $11 / 01 / 09-36$ & ICa & $x$ & 11.3 & 1.0 \\
\hline 25 & PV-1 & $2016-05-17$ & $10: 50$ & 38742 & $11 / 01 / 08-1234$ & Ica & $\mathrm{x}$ & 4.8 & 0.7 \\
\hline 26 & PV-5 & $2016-05-18$ & $10: 25$ & 38743 & $11 / 01 / 08-626$ & Ica & $x$ & 9.6 & 0.9 \\
\hline 27 & PV-7 & $2016-05-18$ & $11: 30$ & 38744 & $11 / 01 / 08-1115$ & Ica & $\mathrm{x}$ & 7.3 & 0.7 \\
\hline 28 & PV-12 & 2016-05-17 & $12: 20$ & 38745 & $11 / 01 / 08-841$ & Ica & $\mathrm{x}$ & 4.1 & 0.6 \\
\hline 29 & PV-13 & $2016-05-18$ & $14: 45$ & 38746 & $11 / 01 / 08-716$ & Ica & $x$ & 9.0 & 0.8 \\
\hline 30 & PV-14 & 2016-05-18 & $13: 10$ & 38747 & $11 / 01 / 08-169$ & Ica & $x$ & 10.4 & 0.9 \\
\hline 31 & PV-15 & $2016-05-18$ & $12: 30$ & 38748 & $11 / 01 / 08-154$ & ICa & $x$ & 8.0 & 0.8 \\
\hline 32 & PV-16 & 2016-05-18 & $13: 36$ & 38749 & $11 / 01 / 08-332$ & ICa & $\mathrm{x}$ & 9.7 & 0.9 \\
\hline 33 & PV-17 & $2016-05-18$ & $10: 25$ & 38750 & $11 / 02 / 00-315$ & ICa & $\mathrm{x}$ & 9.4 & 0.9 \\
\hline 34 & PV-20 & $2016-05-17$ & $16: 33$ & 38751 & $11 / 01 / 08-969$ & Ica & $x$ & 4.1 & 0.6 \\
\hline 35 & PV-23 & $2016-05-17$ & 13:50 & 38752 & $11 / 02 / 08-378$ & Ica & $x$ & 5.3 & 0.9 \\
\hline 36 & PL-2 & 2016-05-19 & $11: 10$ & 38753 & $11 / 05 / 06-753$ & Pisco & $x$ & 9.2 & 0.9 \\
\hline 37 & PL-3 & $2016-05-20$ & $13: 30$ & 38754 & $11 / 05 / 06-13$ & Pisco & $\mathrm{x}$ & 7.5 & 0.8 \\
\hline 38 & PL-10 & $2016-05-20$ & $15: 05$ & 38755 & $11 / 05 / 05-652$ & Pisco & $x$ & 8.7 & 0.8 \\
\hline 39 & PL-12 & $2016-05-18$ & $18: 20$ & 38756 & $11 / 05 / 05-275$ & Pisco & $x$ & 17.3 & 1.4 \\
\hline 40 & PL-13 & $2016-05-20$ & $12: 45$ & 38757 & $11 / 05 / 05-930$ & Pisco & $\mathrm{x}$ & 7.3 & 0.8 \\
\hline 41 & PL-16 & $2016-05-20$ & $8: 50$ & 38758 & Laguna Morón & Pisco & $\mathrm{x}$ & 11.7 & 1.0 \\
\hline 42 & PL-18 & $2016-05-20$ & $10: 20$ & 38759 & Laguna La Palma & Pisco & $x$ & 9.2 & 0.9 \\
\hline
\end{tabular}

Tritium is reported in Tritium Units.

$1 T U=3.221$ Picocurries/L per IAEA, 2000 Report.

$1 \mathrm{TU}=0.11919$ Becquerels/L per LAEA, 2000 Report.

Approved by:

Ozfan SStach

Orfan shouakar-Stash, PhD

Director

Isotope Tracer Technologies inc.

695 Rupert St. Unit B, Waterioo, ON, N2V 125

Tel: 519-886-5955 | Fax: 519-886-5975

Email: ortan fitzisotopes.com

Website: www. itzisotopes.com 


2016
ISOTOPE TRACER

File Number: $\quad \underline{160185}$

\begin{tabular}{|c|c|c|c|c|c|c|c|c|c|}
\hline$\#$ & Sample ID & Collec & & Sample\# & Sample Name (local) & Location & $\delta^{13} \mathrm{c}$ & Result & Repeat \\
\hline & & Date & Time & & & & DIC & PDB & \\
\hline 1 & P1 & $2016-05-23$ & $17: 10$ & 38718 & Laguna Orcococha & Castrovirreyna & & & \\
\hline 2 & $p_{2}$ & $2016-05-23$ & $17: 50$ & 38719 & Laguna Choclococha & Castrovirreyna/Huatytara & $\mathrm{x}$ & -7.7 & \\
\hline 3 & P3 & $2016-05-24$ & $7: 20$ & 38720 & Laguna Ccaracocha & Huaytara & & & \\
\hline 4 & p5 & $2016-05-24$ & $13: 40$ & 38721 & Manantial Chaulisma & Huaytara & & & \\
\hline 5 & PB & $2016-05-24$ & $18: 00$ & 38722 & Manantial Qda. Aguacha(Santiago) & Huavtara & $x$ & -13.3 & \\
\hline 6 & R1 & $2016-05-25$ & $8: 22$ & 38723 & Rio Tambo & Huaytara & & & \\
\hline 7 & R2 & $2016-05-25$ & $8: 00$ & 38724 & Rio Santiago & Huaytara & & & \\
\hline 8 & R3-A & $2016-05-25$ & $8: 25$ & 38725 & Rio Ica (challaca) & Huaytara & $x$ & -11.1 & \\
\hline 9 & R4-B & 2016-05-19 & $18: 30$ & 38726 & Río Pisco (Pte. Murga) & Pisco & & & \\
\hline 10 & $\mathrm{Pl}-2$ & $2016-05-27$ & $13: 55$ & 38727 & $11 / 01 / 04-0296$ & Ica & $x$ & -14.4 & -14.5 \\
\hline 11 & Pl-3 & $2016-05-27$ & 14:30 & 38728 & 11/01/04-0039 & Ica & & & \\
\hline 12 & Pl-5 & $2016-05-27$ & $15: 00$ & 38729 & $11 / 01 / 11-0509$ & Ica & & & \\
\hline 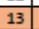 & Pl-8 & $2016-05-27$ & $7: 55$ & 38730 & $11 / 01 / 14-30$ & ICa & $x$ & -11.7 & \\
\hline 14 & Pl-10 & $2016-05-27$ & $7: 00$ & 38731 & $11 / 01 / 14-65$ & Ica & $x$ & -10.6 & \\
\hline 15 & Pl-13 & $2016-05-27$ & $8: 50$ & 38732 & $11 / 01 / 05-70$ & Ica & & & \\
\hline 16 & Pl-14 & $2016-05-22$ & $8: 40$ & 38733 & $11 / 01 / 13-8$ & ICa & $x$ & -14.7 & \\
\hline \begin{tabular}{|l|l|}
17 \\
\end{tabular} & $\mathrm{Pl}-15$ & $2016-05-27$ & $10: 20$ & 38734 & $11 / 01 / 03-77$ & Ica & & & \\
\hline 18 & $\mathrm{Pl}-16$ & $2016-05-26$ & $16: 25$ & 38735 & $11 / 01 / 01-431$ & Ica & & & \\
\hline \begin{tabular}{|l|}
19 \\
\end{tabular} & $\mathrm{Pl}-17$ & $2016-05-26$ & $15: 30$ & 38736 & $11 / 01 / 01-207$ & Ica & $x$ & -13.5 & \\
\hline 20 & $\mathrm{Pl}-22$ & $2016-05-26$ & $8: 22$ & 38737 & $11 / 01 / 02-73$ & Ica & & & \\
\hline 21 & $\mathrm{Pl}-24$ & $2016-05-26$ & $9: 15$ & 38738 & $11 / 01 / 02-53$ & Ica & & & \\
\hline 22 & $\mathrm{Pl}-25$ & $2016-05-26$ & 14:50 & 38739 & $11 / 01 / 10-49$ & Ica & & & \\
\hline \begin{tabular}{|l|l|}
23 \\
\end{tabular} & $\mathrm{Pl}-26$ & $2016-05-26$ & $12: 20$ & 38740 & $11 / 01 / 10-20$ & ICa & $x$ & -12.4 & \\
\hline 24 & Pl-28 & $2016-05-26$ & $9: 50$ & 38741 & $11 / 01 / 09-36$ & Ica & $x$ & -11.6 & -11.6 \\
\hline 25 & PV-1 & $2016-05-17$ & $10: 50$ & 38742 & $11 / 01 / 08-1234$ & Ica & $x$ & -13.6 & -13.5 \\
\hline 26 & PV-5 & $2016-05-18$ & $10: 25$ & 38743 & $11 / 01 / 08-626$ & Ica & & & \\
\hline \begin{tabular}{|l|l}
27 \\
\end{tabular} & PV-7 & $2016-05-18$ & $11: 30$ & 38744 & $11 / 01 / 08-1115$ & ICa & $x$ & -12.4 & \\
\hline 28 & PV-12 & $2016-05-17$ & $12: 20$ & 38745 & $11 / 01 / 08-841$ & Ica & & & \\
\hline 29 & PV-13 & $2016-05-18$ & $14: 45$ & 38746 & $11 / 01 / 08-716$ & Ica & & & \\
\hline 30 & PV-14 & $2016-05-18$ & $13: 10$ & 38747 & $11 / 01 / 08-169$ & Ica & & & \\
\hline 31 & PV-15 & $2016-05-18$ & $12: 30$ & 38748 & $11 / 01 / 00-154$ & Ica & $x$ & -11.0 & \\
\hline \begin{tabular}{l|l}
32 \\
\end{tabular} & PV-16 & $2016-05-18$ & $13: 36$ & 38749 & $11 / 01 / 08-332$ & Ica & & & \\
\hline 33 & PV-17 & $2016-05-18$ & $10: 25$ & 38750 & $11 / 02 / 08-315$ & ICa & $x$ & -13.0 & -12.5 \\
\hline 34 & PV-20 & $2016-05-17$ & $16: 33$ & 38751 & $11 / 01 / 08-969$ & Ica & $x$ & -8.9 & \\
\hline 35 & PV-23 & $2016-05-17$ & $13: 50$ & 38752 & $11 / 02 / 08-378$ & Ica & $x$ & -10.4 & \\
\hline 36 & $\mathrm{PL}-2$ & $2016-05-19$ & 11:10 & 38753 & $11 / 05 / 06-753$ & Pisco & $x$ & -9.5 & \\
\hline 37 & PL-3 & $2016-05-20$ & $13: 30$ & 38754 & $11 / 05 / 06-13$ & Pisco & & & \\
\hline 38 & PL-10 & $2016-05-20$ & $15: 05$ & 38755 & $11 / 05 / 05-652$ & Pisco & & & \\
\hline \begin{tabular}{|l|l|}
39 \\
\end{tabular} & PL-12 & $2016-05-18$ & $18: 20$ & 38756 & $11 / 05 / 05-275$ & Pisco & $x$ & -13.2 & \\
\hline 40 & PL-13 & $2016-05-20$ & $12: 45$ & 38757 & $11 / 05 / 05-930$ & Pisco & & & \\
\hline \begin{tabular}{l|l}
41 \\
\end{tabular} & PL-16 & $2016-05-20$ & 8:50 & 38758 & Laguna Morón & Pisco & & & \\
\hline 42 & PL-18 & $2016-05-20$ & $10: 20$ & 38759 & Laguna La Palma & Pisco & & & \\
\hline
\end{tabular}

Instrument Used:

Finnigan Mat, Delta ${ }^{\text {Ple }}$ XI IRMS, Germany.

Standard Used:

$\Pi^{2}-27$

$\Pi^{2}-34$

NBS-18

NBS-19

Typical Standard deviation:

$=0.2 \%$

Approved by.

Orfan SStash

orfan Shouakar-stash, PhD

Director

Isotope Tracer Technologies inc.

695 Rupert St. Unit B, Waterloo, ON, N2V 125

Tel: 519-886-5959 | Fox: 519-886-5979

Email: orfaneitzisotopes.com 


\section{MInstitute ${ }^{\text {Macrothink }}$}

Environmental Management and Sustainable Development

ISSN 2164-7682 2020, Vol. 9, No. 2

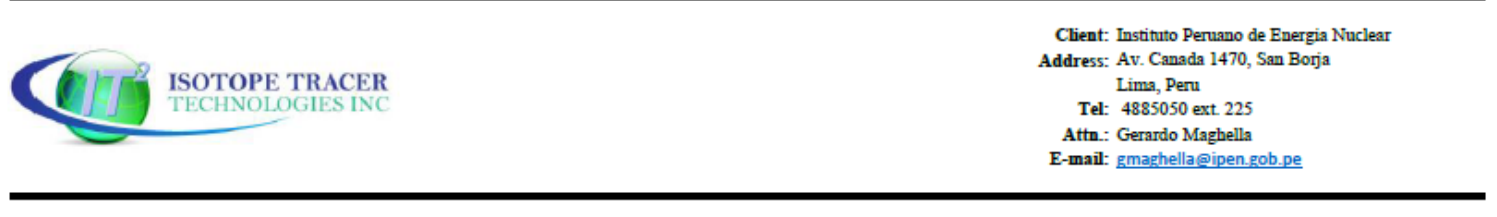

File Number: $\quad \underline{160185}$

\begin{tabular}{|c|c|c|c|c|c|c|c|c|c|c|c|}
\hline \multirow[t]{2}{*}{$\#$} & \multirow[t]{2}{*}{ Sample ID } & \multicolumn{2}{|c|}{ collection } & \multirow[t]{2}{*}{ Sample \# } & \multirow[t]{2}{*}{ Sample Name (local) } & \multirow[t]{2}{*}{ Location } & \multirow{2}{*}{$\begin{array}{l}{ }^{14} \mathrm{C} \\
\mathrm{DIC}\end{array}$} & \multicolumn{2}{|c|}{ Fraction of Modern } & \multicolumn{2}{|c|}{${ }^{14} \mathrm{CYr}$} \\
\hline & & Date & Time & & & & & pmc & $\pm 1 \sigma$ & $B P$ & \pm 10 \\
\hline 1 & $\begin{array}{llll}\mathbf{P 1} & & & \\
\end{array}$ & $2016-05-23$ & $17: 10$ & 38718 & Laguna Orcococha & Castrovirreyna & & & & & \\
\hline 2 & P2 & $2016-05-23$ & $17: 50$ & 38719 & Laguna Choclococha & Castrovirreyna/Huatytara & $x$ & 73.83 & 0.27 & 2437 & 30 \\
\hline 3 & P3 & $2016-05-24$ & $7: 20$ & 38720 & Laguna Ccaracocha & Huaytara & & & & & \\
\hline 4 & P5 & $2016-05-24$ & $13: 40$ & 38721 & Manantial Chaulisma & Huaytara & & & & & \\
\hline 5 & PB & $2016-05-24$ & $18: 00$ & 38722 & Manantial Qda. Aguacha(Santiago) & Huaytara & $x$ & 98.15 & 0.25 & 150 & 21 \\
\hline 6 & R1 & $2016-05-25$ & $8: 22$ & 38723 & Rio Tambo & Huaytara & & & & & \\
\hline 7 & R2 & $2016-05-25$ & $8: 00$ & 38724 & Rio Santiago & Huaytara & & & & & \\
\hline 8 & R3-A & $2016-05-25$ & $8: 25$ & 38725 & Rio Ica (Challaca) & Huaytara & $x$ & 92.07 & 0.24 & 664 & 21 \\
\hline 9 & R4-B & $2016-05-19$ & 18:30 & 38726 & Río Pisco (Pte. Murga) & Pisco & & & & & \\
\hline 10 & $\mathrm{Pl}-2$ & $2016-05-27$ & 13:55 & 38727 & $11 / 01 / 04-0296$ & Ica & $x$ & 92.2 & 0.24 & 653 & 21 \\
\hline 11 & $\mathrm{Pl}-3$ & $2016-05-27$ & $14: 30$ & 38728 & 11/01/04-0039 & Ica & & & & & \\
\hline 12 & Pl-5 & $2016-05-27$ & $15: 00$ & 38729 & $11 / 01 / 11-0509$ & Ica & & & & & \\
\hline 13 & $\mathrm{Pl}-8$ & $2016-05-27$ & $7: 55$ & 38730 & $11 / 01 / 14-30$ & Ica & $x$ & 74.23 & 0.19 & 2394 & 21 \\
\hline 14 & $\mathrm{Pl}-10$ & $2016-05-27$ & $7: 00$ & 38731 & $11 / 01 / 14-65$ & Ica & $x$ & 78.75 & 0.21 & 1919 & 22 \\
\hline 15 & $\mathrm{Pl}-13$ & $2016-05-27$ & $8: 50$ & 38732 & $11 / 01 / 05-70$ & Ica & & & & & \\
\hline 16 & $\mathrm{Pl}-14$ & $2016-05-22$ & $8: 40$ & 38733 & $11 / 01 / 13-8$ & Ica & $x$ & 89.93 & 0.23 & 852 & 21 \\
\hline 17 & Pl-15 & $2016-05-27$ & $10: 20$ & 38734 & $11 / 01 / 03-77$ & Ica & & & & & \\
\hline 18 & Pl-16 & $2016-05-26$ & $16: 25$ & 38735 & $11 / 01 / 01-431$ & Ica & & & & & \\
\hline 19 & $\mathrm{Pl}-17$ & $2016-05-26$ & $15: 30$ & 38736 & $11 / 01 / 01-207$ & ICa & $x$ & 75.59 & 0.21 & 2248 & 22 \\
\hline 20 & P1-22 & $2016-05-26$ & $8: 22$ & 38737 & $11 / 01 / 02-73$ & ICa & & & & & \\
\hline 21 & $\mathrm{Pl}-24$ & $2016-05-26$ & 9:15 & 38738 & $11 / 01 / 02-53$ & Ica & & & & & \\
\hline 22 & $\mathrm{Pl}-25$ & $2016-05-26$ & $14: 50$ & 38739 & $11 / 01 / 10-49$ & Ica & & & & & \\
\hline 23 & $\begin{array}{ll}\mathrm{Pl}-26 \\
\end{array}$ & $2016-05-26$ & $12: 20$ & 38740 & $11 / 01 / 10-20$ & ICa & $x$ & 98.73 & 0.26 & 103 & 21 \\
\hline 24 & $\mathrm{Pl}-28$ & $2016-05-26$ & 9:50 & 38741 & $11 / 01 / 09-36$ & Ica & $x$ & 96.49 & 0.25 & 287 & 21 \\
\hline 25 & $\begin{array}{ll}\text { PV-1 } \\
\end{array}$ & $2016-05-17$ & $10: 50$ & 38742 & $11 / 01 / 08-1234$ & ICa & $x$ & 99.11 & 0.26 & 71 & 21 \\
\hline 26 & PV-5 & $2016-05-18$ & $10: 25$ & 38743 & $11 / 01 / 08-626$ & Ica & & & & & \\
\hline 27 & PV-7 & $2016-05-18$ & 11:30 & 38744 & $11 / 01 / 08-1115$ & Ica & $x$ & 62.47 & 0.23 & 3779 & 30 \\
\hline 28 & PV-12 & $2016-05-17$ & $12: 20$ & 38745 & $11 / 01 / 08-841$ & Ica & & & & & \\
\hline 29 & PV-13 & $2016-05-18$ & 14:45 & 38746 & $11 / 01 / 08-716$ & Ica & & & & & \\
\hline 30 & PV-14 & $2016-05-18$ & $13: 10$ & 38747 & $11 / 01 / 08-169$ & Ica & & & & & \\
\hline 31 & PV-15 & $2016-05-18$ & 12:30 & 38748 & $11 / 01 / 08-154$ & Ica & $\mathrm{x}$ & 73.25 & 0.20 & 2501 & 21 \\
\hline 32 & PV-16 & $2016-05-18$ & 13:36 & 38749 & 11/01/08-332 & Ica & & & & & \\
\hline 33 & PV-17 & $2016-05-18$ & $10: 25$ & 38750 & $11 / 02 / 00-315$ & ICa & $x$ & 47.88 & 0.18 & 5917 & 30 \\
\hline 34 & PV-20 & $2016-05-17$ & $16: 33$ & 38751 & $11 / 01 / 08-969$ & Ica & $x$ & 65.45 & 0.18 & 3405 & 23 \\
\hline 35 & PV-23 & 2016-05-17 & 13:50 & 38752 & $11 / 02 / 08-378$ & ICa & $x$ & 34.58 & 0.87 & 8531 & 201 \\
\hline 36 & PL-2 & $2016-05-19$ & $11: 10$ & 38753 & $11 / 05 / 06-753$ & Pisco & $\bar{x}$ & 44.86 & 0.15 & 6439 & 27 \\
\hline 37 & PL-3 & $2016-05-20$ & $13: 30$ & 38754 & $11 / 05 / 06-13$ & Pisco & & & & & \\
\hline 38 & PL-10 & $2016-05-20$ & 15:05 & 38755 & $11 / 05 / 05-652$ & Pisco & & & & & \\
\hline 39 & $\mathrm{PL}-12$ & $2016-05-18$ & $18: 20$ & 38756 & $11 / 05 / 05-275$ & Pisco & $x$ & 31.61 & 0.13 & 9252 & 33 \\
\hline 40 & PL-13 & $2016-05-20$ & 12:45 & 38757 & $11 / 05 / 05-930$ & Pisco & & & & & \\
\hline 41 & PL-16 & $2016-05-20$ & 8:50 & 38758 & Laguna Morón & Pisco & & & & & \\
\hline 42 & PL-18 & 2016-05-20 & $10: 20$ & 38759 & Laguna La Palma & Pisco & & & & & \\
\hline
\end{tabular}

Instrument Used:

AMS (Accelerator Mass Spectrometry)

Standard Used:

ox1: $1.05 \times \mathrm{e}-10$

C. $1.35 \times 0.10$

C6. $1.5 \times$ e-10

Typical Standard deviation:

5 to $10 \%$ of Standrad values listed above

Approved by:

Offan SStash

Orfan Shouakar-Stash, PhD

Director

Isotope Tracer Technologies Inc

695 Rupert St. Unit B, Waterloo, ON, N2V 125

Tel: $519-886-5935$ | Fax: $519-886-5979$

Email: ortaneitzisotopes.com

Website: www.itzisotopes.co

\section{Copyright Disclaimer}

Copyright for this article is retained by the author(s), with first publication rights granted to the journal.

This is an open-access article distributed under the terms and conditions of the Creative Commons Attribution license (http://creativecommons.org/licenses/by/4.0/). 